\title{
Science Communication
}

科学とコミュニケーションを考える

\author{
共感・共有の手法
}

人類はなぜ，他の動物に比べて大きな大脳を持ってい るのでしょうか。これは，進化の過程において人類が選 択した生存戦略に理由があります。人類の祖先は速い逃 げ足を持っているわけでも，鋭い爪や牙を持っているわ けでもありませんでした。そこで，単独で生きていくの ではなく，集団で生き残ることを選択しました。こうし た群れを作る動物は地球上にたくさんいましたが，人類 の戦略は独特でした。心と心を通じ合わせ，コミュニ ケーションすることで，複雑な社会集団を作り上げたの です。そのためには大きな大脳が必要でした。すなわ ち，人間の脳は人間の心とコミュニケートするように進 化してきたのです。

これが共感・共有のコミュニケーションの出発点で す。ですから，共感・共有のコミュニケーションを成立 させるのは意外に簡単で，そこに人間が介在すればいい だけなのです。そうすれば，人間は勝手にその人の心と コミュニケーションを始めます。ゆえに, 最も効果的な 共感・共有のコミュニケーションの方法は, 対人コミュ ニケーションです。

ただし，対人コミュニケーションを有効に機能させる ためには，それなりの工夫が必要です。ここで，2つの 実例に則して，工夫の方法を挙げてみましょう。

最初の例は, 青山学院大学の「岸田アドバイザーグ ループ」の活動です。アドバイザーグループというのは, 教員を中心として結成される学生の集団なのですが，ゼ ミのような課目としての縛りがなく，自由な活動が許さ れる団体です。上記の「岸田アドバイザーグループ」は 2017 年 11 月 5 日に開催された学園祭の機会を利用し て，サイエンスカフェを開催しました。

メインの講演者は, 時間的な余裕がなかったこともあ り，ゲストを呼ばずに私が務めました。対人コミュニ ケーションを成功させるための前提として, 企画の段階 から聴衆の具体的な人物像(マーケティングの用語で「ぺ ルソナ」といいます)をしっかりと設定しました。ポス ターにも工夫を施しました。講演者のプロフィールに「理 学博士なのに経済学部教授？」というひと言をいれて，コ ミュニケーションにおける「人間」の部分に興味を持たせ るようにしました。本番の冒頭では，聴衆と講演者と企 画者(学生たち)が混ざって, 簡単なゲームで「アイスブ
青山学院大学 岸田一隆

レーク」を行いました。互いに初対面同士の固い人間関係 を，氷を融かすようにほぐしていきます。この時点で「共 感・共有」のベースができていきます。講演のスライドに も「共感・共有」のための工夫があったのですが，それは省 略します。最後はワークショップに移ります。ここでは, なるべく自分の実体験に基づく発言をしてもらいました。 参加者は，他者がどう考えているかを知り，自分自身の中 で無意識に設定している偏見や前提を，意識の上に取り 出して，再確認することができました。

第 2 の例は，今回のコラムシリーズでたびたび取り上 げている一般市民向け公開シンポジウムです。ここで は, 「共感・共有」のための仕掛けとして，パネル討論の 冒頭に工夫を施しました。各パネリストたちにあらかじ め配っておいた画用紙に「あなたは小学生時代に何にな りたかったですか」という質問に答えてもらいました。 予告なしの抜き打ちですから, 回答にはその人間の地が 出ます。これこそが，私の狙いでした。パネル討論会 は，パネリストと聴衆の間に意識の上での「壁」が生じが ちです。しかも，パネリストは専門家であり，自分とは 違う人種のように感じがちです。ところが，このゲーム を冒頭に行うことによって，「パネリスト」という無機質 な存在ではなく，「生身の人間」が自分に対峙しているよ うに思えるのです。

そして, パネル討論の最後では，2枚目の画用紙に, 「今のあなたの目標や夢は何ですか」という質問に答えて もらいました。最初の質問から最後の質問へ向けて, 過 去から未来へと橋を架け, 未来へのビジョンを持って現 実を選択することを象徴させたのです。

他にも，対人コミュニケーションの手法はいろいろあ ります。しかし，前回にも述べたことですが，悪用の危 険性には十分な注意が必要です。実は, 対人コミュニ ケーションの効果は, 実体験だけではなく, 擬似体験で も同じように働きます。ですから，私たちはドラマや文 学作品に心が摇さぶられ，価值観を変えてしまうことも あるのです。ですが, そんなドラマや文学作品や VR(仮 想現実)が，特定の国や民族をへイトする目的で作られ てしまったら，どんなことになるでしょうか。私たち は，あくまで，よりよき共同体を形成するために，「共 感・共有」を使うべきなのです。（2018 年 7 月 14 日 記) 